\title{
KEGIATAN BAKTI SOSIAL UNTUK MEMBANTU EKONOMI LANSIA DI DESA JAMBEYAN PADA ERA NEW NORMAL
}

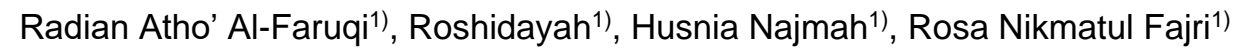 \\ 1) Program Studi S1 Akuntansi, Fakultas Ekonomi, Universitas Islam Batik Surakarta, Surakarta, Jawa tengah, Indonesia \\ Corresponding author : Radian Atho' Al-Faruqi \\ E-mail : radianatho76@gmail.com
}

Diterima 10 November 2020, Direvisi 16 November 2020, Disetujui 16 November 2020

\begin{abstract}
ABSTRAK
Di era new normal merupakan tahapan bagi pemerintah maupun masyarakat untuk menyelesaikan masalah ekonomi yang terjadi di segala lapisan masyarakat. Maka dengan memanfaatkan keadaan new normal ini, maka kami kelompok KKN Tematik Universitas Islam Batik Surakarta yang berjumlah 7 peserta membuat kegiatan bakti sosial dengan memberikan paket sembako pada 16 lansia di Desa Jambeyan, kami memperoleh datanya melalui metode evaluasi hasil wawancara dengan pihak RT desa setempat. Kelompok KKN Tematik Universitas Islam Batik Surakarta melaksanakan kegiatan pembagian sembako dengan tujuan pembagian sembako yang kami berikan kepada 16 lansia bisa membantu perekonomian lansia sehingga mereka mampu untuk mempertahankan kehidupanya.
\end{abstract}

Kata kunci: KKN-T; bakti sosial; new normal.

\begin{abstract}
In the new normal era is a stage for the government and society to solve economic problems that occur in all walks of life. So by utilizing this new normal situation, then we group KKN Thematic Islamic University batik Surakarta which numbered 7 participants made social service activities by providing packages of food to 16 elderly people in Jambeyan Village, we obtained the data through the method of evaluating the results of interviews with local village RT. KkN Thematic Group of Islamic University of Surakarta Batik carried out the activities of the division of food with the aim of sharing the food that we give to 16 elderly people can help the elderly economy so that they can maintain their lives.
\end{abstract}

Keywords: KKN-T; social service; new normal.

\section{PENDAHULUAN}

Pandemi Covid-19 mengguncang tatanan masyarakat hampir seluruh negara di dunia. Covid-19 merupakan penyakit baru dan cepat menular. Pandemi merupakan menyebarnya epidemi penyakit di wilayah yang luas seperti benua, atau seluruh dunia (Wikipedia, 2020). Pandemi yang sedang berlangsung saat ini yaitu Covid-19. Menurut ahli virologis Richard Sutejo, Covid-19 yang disebabkan coronavirus merupakan jenis virus yang menyerang pernafasan (Suara.com, 2020).

Kasus Covid-19 ini berasal dari Wuhan, Tiongkok pada November 2019 (medcom.id, 2020). Situasi tersebut terbukti diluar prediksi manusia. Coronavirus jenis tertentu diketahui mengakibatkan ganguan berupa infeksi saluran pernafasan pada manusia. Infeksi tersebut berupa batuk, pilek serta Middle East Resoiratory Syndrome (MERS) dan Severe Acute Respiratory Syndrome (SARS) (Lestari et. al, 2020). Jenis coronavirus yang ditemukan baru-baru ini menyebabkan penyakit Covid-19.
Demi mencegah menyebarnya virus Covid-19 yang sangat cepat meluas, masyarakat disarankan untuk tinggal dirumah termasuk ibadah, sekolah, bekerja dan kegiatan lainya kecuali ada urusan yang mendesak (Ketua Ikatan Ahli Kesehatan Masyarakat Indonesia, 2020) dalam (kompas.com, 2020). Namun pada 1 Juni 2020 lalu, pemerintah sedikit melonggarkan kebijakan terkait Covid19 (Kompas.com;, 2020). Kebijakan tersebut disebut new normal.

Menurut pemerintah Indonesia, era new normal merupakan era dimana terdapat skenario untuk mengatasi Covid-19 dalam bidang kesehatan serta sosial-ekonomi (tirto.id, 2020). Skenario tersebut bertujuan untuk mencegah penurunan kualitas hidup masyarakat tidak terkecuali para lansia. Untuk beradaptasi di era new normal, para lansia harus tercukupi kehidupanya baik dibidang pangan, maupun kesehatan. Langkah yang baik dilaksanakan dalam kondisi new normal adalah berbagi paket sembako (Media Indonesia, 2020). 
Berbagi sembako adalah salah satu cabang dari bakti sosial yang merupakan bentuk bagian dari pengabdian masyarakat (wikipedia, 2018). Sebagai bentuk implementasi Tri Dharma Perguruan Tinggi, Mahasiswa Universitas Islam Batik Surakarta, Fakultas Ekonomi, Prodi Akuntansi mengadakan sebuah pengabdian masyarakat berupa kegiatan bakti sosial berupa pembagian paket sembako. Dalam pelaksanaanya, kegiatan bakti social berupa pembagian paket sembako didanai oleh iuran anggota salah satu kelompok KKN Tematik Universitas Islam Batik Surakarta 2020.

Bakti bermakna pengikatan, sedangkan sosial bermakna perorangan dan kelompok-kelompok. Sehingga bakti sosial dapat diartikan suatu kegiatan sebagai wujud kepedulian terhadap sesama manusia dimana dengan kegiatan ini, dapat diperoleh keeratan rasa persaudaraan terhadap sesama manusia (Tambunan, Purba, \& Haloho, 2020).

Tujuan diadakanya kegiatan bakti sosial, diharapkan dapat meningkatkan ekonomi masyarakat terutama para lansia. Kegiatan ini ditujukan kepada lansia di desa Jambeyan yang mengalami masalah dalam memenuhi kebutuhan pokok karena pandemi covid-19. Oleh karena itu, kelompok KKN Tematik program studi Akuntansi Fakultas Ekonomi Universitas Islam Batik Surakarta mengadakan kegiatan bakti social.

\section{METODE}

Kegiatan Pembagian Paket Sembako ini di berikan kepada 16 warga lansia di desa Jambeyan Kecamatan Sambirejo kabupaten Sragen. Kegiatan pembagian paket sembako ini dilakukan oleh 7 mahasiswa KKN Tematik Universitas Islam Batik Surakarta, Melalui metode evaluasi wawancara kepada RT setempat untuk mendapatkan data terkait siapa saja yang berhak mendapatkan. Kegiatan dilaksanakan dalam satu hari sesuai jadwal kegiatan. Pelaksanaan pembagian paket sembako dilaksanakan oleh mahasiswa KKN-T UNIBA Surakarta dengan cara membagikan paket sembako secara langsung kepada warga lansia di desa Jambeyan kecamatan Sambirejo kabupaten Sragen. Dilakukan dalam tiga tahap:

1. Tahap pertama yakni meminta izin dan mengumpulkan data warga lansia yang berada di desa Jambeyan Kecamatan Sambirejo kabupaten Sragen.

2. Tahap kedua yakni Persiapan pengemasan paket sembako yang akan disalurkan kepada warga lansia

3. Tahap ketiga yakni pembagian paket sembako kepada warga lansia guna membantu perekonomian mereka dimasa new normal saat ini

\section{HASIL DAN PEMBAHASAN}

Saat pelaksanaan pembagian sembako tetap memperhatikan protocol kesehatan di masa pandemi saat ini. Kegiatan pembagian paket sembako dilakukan dalam tiga tahap.

1. Tahap pertama yakni permohonan izin ke ketua RT untuk mengadakan bakti sosial ini dan juga meminta data warga desa Jambeyan Kecamatan Sambirejo kabupaten Sragen yang tergolong lansia yang mengalami masalah dalam hal pemenuhan kebutuhan pokok di era normal baru saat ini. dapat dilihat pada gambar 1 dibawah ini.

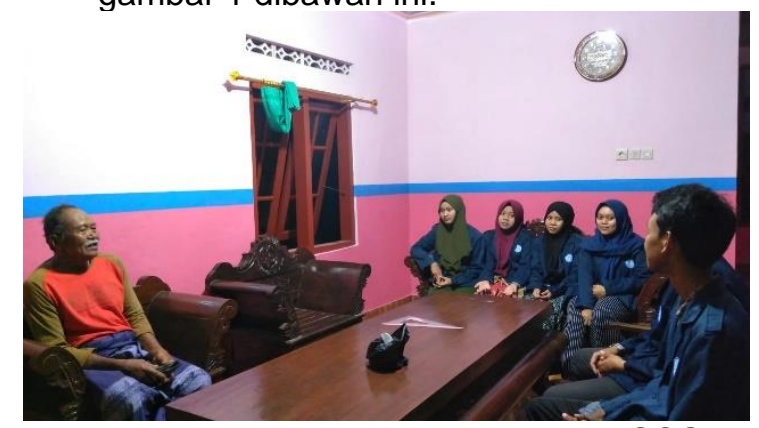

Gambar 1. Perizinan Pengadaan BAKSOS \& Pendataan warga lansia

2. Tahap kedua yakni Persiapan Pengemasan Paket Sembako berupa gula $1 \mathrm{~kg}$, telur $1 / 2 \mathrm{~kg}$ dan 2 pcs mie instan yang akan disalurkan kepada warga lansia yang sudah didata oleh ketua RT setempat.

3. Tahap ketiga yakni waktu pelaksanaan pembagian paket sembako ke masyarakat lansia guna membantu perekonomian di masa normal baru saat ini. Pelaksanaan Bakti Sosial (Pembagian paket sembako) ini dilakukan desa Jambeyan Kecamatan Sambirejo kabupaten Sragen dan diserahkan pada warga lansia yang kesulitan dalam memenuhi kebutuhan perekonomiannya dalam kondisi new normal seperti saat ini. Warga yang menerima paket sembako kurang lebih 16 orang, kegiatan penyerahan dilaksanakan pada hari Minggu, 01 November 2020. Kegiatan tersebut dapat dilihat pada gambar 2 dan gambar 3 dibawah ini. 


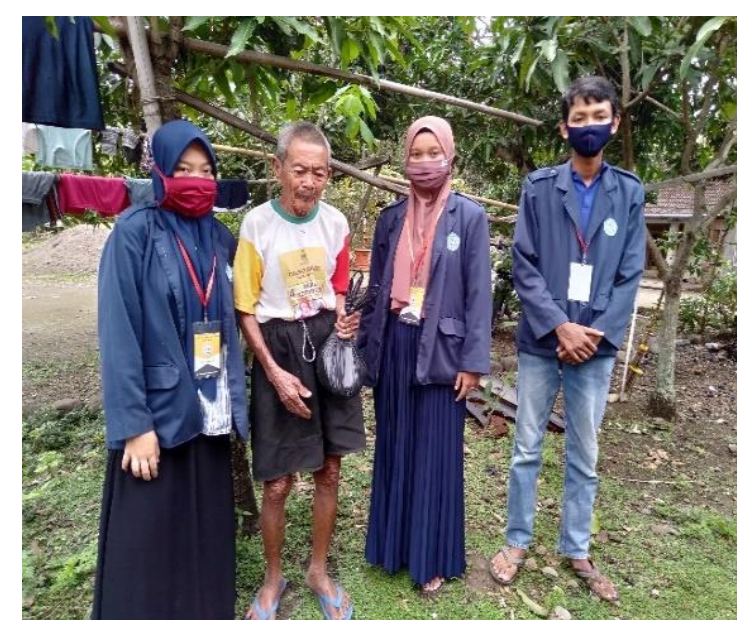

Gambar 2. Penyerahan paket sembako.

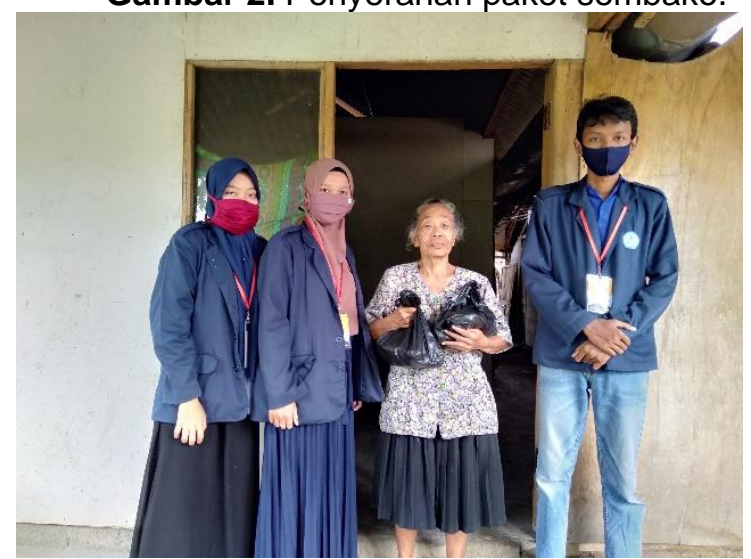

Gambar 3. Penyerahan paket sembako

Dampak dari pembagian sembako adalah membantu lansia untuk mempertahankan kehidupanya

\section{SIMPULAN DAN SARAN}

Berdasaran dari hasil pengabdian KKN-T UNIBA SURAKARTA yang dilakukan di desa Jambeyan Kecamatan Sambirejo kabupaten Sragen tentang Kegiatan Bakti Sosial untuk membantu Ekonomi pada Era normal baru dapat disimpulkan bahwa kegiatan bakti sosial dengan membagikan sembako kepada 16 lansia yang ada di desa Jambeyan Kecamatan Sambirejo kabupaten Sragen dapat sedikit membantu ekonomi lansia yang ada di wilayah tersebut.

Saran dari tim adalah menambah jenis sembako yang dibagikan karena pada kegiatan tersebut hanya mencakup gula $1 \mathrm{~kg}$, telur $1 / 2 \mathrm{~kg}$ dan 2 pcs mie instan. Saran selanjutnya adalah memperluas objek yang akan diberi sembako sehingga diperoleh pemerataan yang lebih.

\section{UCAPAN TERIMAKASIH}

Ucapan terima kasih kepada pihak yang telah memberikan kontribusi pada pelaksaan kegiatan ini sehingga dapat berjalan dengan baik sesuai dengan perencanaan. Tim penulis mengucapkan terima kasih kepada Bapak Ketua RT yang membantu kami dalam pengumpulan data sehingga kegiatan ini dapat berjalan dengan baik.

\section{DAFTAR RUJUKAN}

kompas.com. (2020). Nasional. Retrieved 2020, from Kompas.com: https://nasional.kompas.com/read/202 0/03/23/10371551/cegah-covid-19masyarakat-diminta-tetap-di-rumahhingga-akhir-maret-2020?page=all

Kompas.com;. (2020, Mei 26). Mulai 1 Juni, Ini Skenario Tahapan New Normal untuk Pemulihan Ekonomi. Retrieved 11 13, 2020,

from https://money.kompas.com/read/2020/ 05/26/073708726/mulai-1-juni-iniskenario-tahapan-new-normal-untukpemulihan-ekonomi?page=all

Lestari et. al, C. I. (2020). Penyuluhan Tentang Cuci Tangan Pakai Sabun (CTPS) Untuk Mencegah Peyebaran Coronavirus (COV) di Wilayah Kerja Puskesmas Karang Pule. SELAPARANG. Jurnal Pengabdian Masyarakat Berkemajuan, 4(1), 370373.

medcom.id. (2020, 06 12). medcom.id. Retrieved 11 13, 2020, from https://m.medcom.id/rona/kesehatan/z NPGg7OK-kasus-pertamacoronavirus-di-tiongkok-ditelusuriterjadi-pada-november

Media Indonesia. (2020). Humaniora. Retrieved 2020, from Media Indonesia: https://m.mediaindonesia.com/read/det ail/300323-penyalurkan-sembako-kewarg-terdampak-covid-19dimatangkan

Suara.com. (2020). Health/Konsultasi. Retrieved 2020, from Suara.com: https://www.suara.com/health/2020/04/ 13/183832/ahli-virus-sebut-covid-19adalah-virus-umum-tetapi?page=all

Tambunan, E., Purba, M. L., \& Haloho, E. (2020). Pendampingan Gerakan Bakti Sosial Berbagi Paket Sembako Peduli Covid-19 HIMA Manajeman Universitas Sari Mutiara Indonesia. Jurnal Abdimas Mutiara, 1(2), 58-63.

tirto.id. (2020, 05 29). tirto.id. Retrieved 11 13, 2020, from https://tirto.id/arti-newnormal-indonesia-tatanan-baruberadaptasi-dengan-covid-19-fDB3

wikipedia. (2018). wikipedia.org. Retrieved 2020, from https://id.m.wikipedia.org/wiki/Pengabd ian_masyarakat

Wikipedia. (2020). Pandemi. Retrieved 2020, from wikipedia. 